\title{
Ecofriendly Method for Suppressing Damping-off Disease Caused by Rhizoctonia solani Using Compost Tea
}

\author{
Ashraf M. Nofal, ${ }^{\mathrm{a}}$ Mohamed Abd El-Rahman, ${ }^{\mathrm{b}}$ Asmaa A. Alharbi, ${ }^{\mathrm{c}}$ and \\ Tarek M. Abdelghany ${ }^{\mathrm{d}}$
}

\begin{abstract}
Compost tea has a lot of potential for sustainable agriculture. The suppressive effect of compost tea on damping-off disease in beans (Phaseolus vulgaris), caused by Rhizoctonia solani, was investigated. The physicochemical properties of the tested compost tea showed the presence of dissolved solids $\left(7070 \mathrm{mgL}^{-1}\right)$, organic matter $\left(1280 \mathrm{mgL}^{-1}\right)$, nitrate $\left(3840 \mathrm{mgL}^{-1}\right)$, and ammonium $\left(90.0 \mathrm{mgL}^{-1}\right)$. The concentrations of phosphorus, potassium, calcium, and magnesium in compost tea were $22.7,1540,214$, and $2.40 \mathrm{mgL}^{-1}$, respectively. The highest inhibition of $R$. solani growth at a concentration of $30 \%$ compost tea filtrate was $87.0 \%$ and it was completely inhibited at a concentration of $50 \%$. The application of compost tea or chemical fungicide (Rizolex-T) significantly decreased the pre- and post-emergence of damping-off and enhanced the plants survival. In spite of the total phenol content in bean plants infected with $R$. solani (15.6 $\mu \mathrm{g} \cdot \mathrm{g}^{-1}$ fresh weight), the treatment of infected plants using compost tea and the Rizolex-T caused further elevation in the phenol content, to 17.5 and $14.7 \mu \mathrm{g} \cdot \mathrm{g}^{-1}$ fresh weight, respectively. These findings support the use of compost tea as a potential alternative to synthetic fungicides to help achieve environmental sustainability and food safety in farming.
\end{abstract}

Keywords: Ecofriendly Compost tea; Rhizoctonia solani; Bean plants; Damping-off disease

Contact information: a: Sustainable development Department, Environmental Studies and Research Institute, University of Sadat City, Menofia Governorate, Sadat City 32897 Egypt; b: Natural Resources Assessment Department, Environmental Studies and Research Institute. University of Sadat City, Menofia Governorate, Sadat City 32897 Egypt; c: Biology Department, Faculty of Science, Jazan University, Jazan, Saudi Arabia; d: Botany and Microbiology Department, Faculty of Science, Al-Azhar University, Cairo 11725 Egypt; *Corresponding author: tabdelghany.201@azhar.edu.eg; tabdelghany@yahoo.com

\section{INTRODUCTION}

Excessive use of chemical pesticides to combat pests pollutes the environment. In addition, plant diseases are also resistant to chemical insecticides. As such, compost teas have a lot of potential in sustainable agriculture. Analytically characterized aerated compost tea (ACT), derived from garden trash, has been evaluated in vitro and in vivo on tomato and bean plants to determine its suppressive effect on Rhizoctonia solani and Fusarium oxysporum (Morales-Corts et al. 2018). Compost teas are organic solutions made from compost fermented in a liquid phase for a few days, with or without aeration. In general, extracts are made by combining mature compost with tap water in a 1 to 5 to 1 to 10 (v/v) ratio (Al-Dahmani et al. 2003). The capacity of these teas to reduce a wide spectrum of soil and airborne diseases is prompting their usage in agriculture (St. Martin 2014). Compost teas are being considered as potential alternatives to the usage of popular 
synthetic fungicides in response to the growing need for environmental sustainability and food safety in agriculture (Pane et al. 2012). Furthermore, the soil-borne pathogens Rhizoctonia solani and Fusarium oxysporum cause disease in a wide range of cultivated plants, particularly in tomato crops (Morales-Corts et al. 2018).

Compost teas are one of the possible alternative biological techniques to combating soilborne illnesses in herbal plants, which result in a considerable reduction in crop yield. It is important to utilize it to prevent, inhibit, or control a variety of soilborne plant diseases, particularly those caused by fungal phytopathogens (Din et al. 2018).

The biological control of plant diseases is seen as a feasible alternative method of disease management (Abdel-Ghany et al. 2009; Abdel-Ghany and Bakri 2019). In many places, the use of biological controls involving hostile microbes has proven to be effective in managing certain plant diseases (Janisiewicz et al. 2000). The majority of these studies have focused on the management of root and soil-borne plant diseases, as well as foliar infections to a lesser extent (Whipps and Lumsden 2001). Compost has the potential to provide the natural biological control of primarily soil-associated illnesses, but its use is currently limited to the rhizosphere (Hoitink et al. 2001). As a result, researchers and organic growers all over the world have used aqueous extracts of compost or compost tea (CT) as foliar sprays to reduce foliar diseases on crops, e.g., apple scab disease (Cronin et al. 1996); powdery mildew disease on roses and tomatoes, grey mould diseases on vegetables, strawberries, geraniums, and tomatoes (Koné et al. 2010); damping-off disease on cucumber seedlings (Scheuerell and Mahaffee 2004); potato late blight (Al-Mughrabi 2007); potato tuber common scab (Al-Mughrabi et al. 2008); and Choanephora wet rot (Sang and Kim 2011).

Composted organic waste has been shown in numerous studies to have the ability to boost plant development and inhibit soil-borne illnesses, in addition to replacing peat as a growth substrate. Compost teas, both aerated and non-aerated, have been demonstrated to control soil-borne diseases, e.g., damping-off, and root rots, e.g., Pythium ultimum and Rhizoctonia solani (Scheuerell and Mahaffee 2004; Dionne et al. 2012). Hoitink and Fahy (1986) found that the actions of microorganisms in compost suppressed various plant diseases.

The common bean (Phaseolus vulgaris L.) belongs to family Fabaceae and is one of the most important leguminous vegetable crops in Egypt. It is considered an important staple food around the world, which provides a considerable amount of plant proteins, minerals, dietary fibers, and carbohydrates (Saleh et al. 2018). It also improves soil fertility through soil nitrogen fixation (Abiot 2018). The global cultivated area of green beans is approximately 1.6 million ha, which produced approximately 23.6 million tonnes. The objective of this study was to evaluate the potential of compost tea as a bioagent in terms of controlling the soil-borne phytopathogen $R$. solani, under in vitro and in vivo conditions.

\section{EXPERIMENTAL}

\section{Isolation, Purification, and Identification of Rhizoctonia solani}

Diseased bean roots ( $P$. vulgaris L.) with damping-off disease were gathered from various areas of the Elmenofya governorate (Shebin El kom, Kafer Dawood, and Bader) and cleaned in flowing tap water before being washed with sterile water. The roots were chopped into small pieces with a sterile scalpel $\left(1\right.$ to $\left.2 \mathrm{~cm}^{2}\right)$. For surface sterilization, the pieces were submerged in a $0.1 \%$ hypochlorite solution (disinfectant solution) for 3 min. 
The residual disinfectant solution was rinsed out of the surface sterilized pieces numerous times with sterilized water. The fragments were then dried on filter papers that had been sterilized. The dry pieces were then put into Petri dishes with potato dextrose agar medium (PDA) treated with an antibacterial agent using sterile forceps $(5 \mathrm{mg} / \mathrm{L}$ of Lchloramphenicol and $5 \mathrm{mg} / \mathrm{L}$ of streptomycin sulphate). The dishes were then incubated at a temperature of $28{ }^{\circ} \mathrm{C}$ for $2 \mathrm{~d}$ before being tested for fungal development. Mycelium fragments were used to purify the resulting isolates (Shabana 1987). Pure cultures of the isolated fungi were identified according to methods outlined in Domsch et al. (1980).

\section{Pathogenicity Test for Rhizoctonia solani}

Isolates of Rhizoctonia solani strains from diseased bean roots (P. vulgaris $\mathrm{L}$.) with damping-off disease were cultivated on barley grain medium, which promoted mycelial development and multiplication. Each of the $500 \mathrm{~mL}$ glass bottles held $200 \mathrm{~g}$ of a wheat bran and sand mixture (a 1 to 3 ratio) and was wet with water and autoclaved for $30 \mathrm{~min}$. The pathogenic strains that had been developed on PDA were separately injected into the prepared bottles and incubated at a temperature of $28{ }^{\circ} \mathrm{C}$ for $14 \mathrm{~d}$. Each pot holding $3 \mathrm{~kg}$ of sterile sandy-clay soil was compacted into a $25 \mathrm{~cm}$ diameter plastic pot with a $25 \mathrm{~cm}$ diameter. One week before sowing the bean seeds, the soil was inoculated (at a rate of $1 \mathrm{~g}$ of inoculum per $1 \mathrm{~kg}$ of soil). To allow mycelial growth and dispersion, the soil was kept moist. In order to assess the pathogenicity of several $R$. solani strains, twenty seeds of sensitive $P$. vulgaris (Giza 6) were sowed in each plastic container (the seeds were purchased from Agronomy Research Institute, Giza, Egypt). All measurements in this investigation were done in duplicate (Mahmoud et al. 2007).

For each treatment, 15 and $30 \mathrm{~d}$ after sowing, both the pre- and post-emergence damping-off (percent infection) were estimated according to Eq. 1:

$$
\text { Infection } \%=\frac{\text { Number of infected plants }}{\text { Total plant number }} \times 100
$$

The percentage of plants that survived (\% survival) was calculated $45 \mathrm{~d}$ after sowing for each treatment according to Eq. 2:

$$
\text { Survival } \%=\frac{\text { Number of uninfected plants }}{\text { Total plant number }} \times 100
$$

\section{Compost Tea Experiments}

\section{Preparation of compost teas}

The compost teas were made using samples from a variety of commercially available composts, both plants (Grape) and animal manures, collected from the Ecad firm in Sadat City, Egypt. To make non-aerated compost tea (NCT) from various composts, 100 $\mathrm{g}$ of compost was mixed with $400 \mathrm{~mL}$ of sterile distilled water in 1-1 Erlenmeyer flasks at a weight-to-volume ratio of 1 to 4 . (w:v). The mixture was homogenized in the dark for 14 $\mathrm{d}$ in an orbital shaker at $150 \mathrm{rev} / \mathrm{min}$ and a temperate of $25^{\circ} \mathrm{C}$. The mixture was loosely covered and stored at the same temperature $\left(25^{\circ} \mathrm{C}\right.$ for $14 \mathrm{~d}$ in the dark) to get NCT. The solid fraction was extracted afterwards, and the extracts were stored at a temperate of $4{ }^{\circ} \mathrm{C}$ until needed (Koné et al. 2010).

Physico-chemical of non-aerated compost tea (NCT)

Standard procedures were used to analyze the mineral composition of the generated $\mathrm{NCT}$, which had a ratio of 1 to $4(\mathrm{w}: \mathrm{v})$. Atomic absorption spectroscopy was used to 
determine the amounts of potassium, sodium, calcium, and magnesium. The concentrations of $\mathrm{NO}_{3}{ }^{-}, \mathrm{PO}_{4}^{-}, \mathrm{SO}_{4}{ }^{-2}$, and $\mathrm{NH}_{4}{ }^{+}$were measured using a UV-visible spectrophotometer. For the NCT, the electrical conductivity (EC) and pH were also measured (Marín et al. 2013).

\section{Effect of non-aerated compost tea (NCT) on mycelial growth of Rhizoctonia solani}

The goal of the assay was to see whether NCT could stop phytopathogen mycelial proliferation in vitro. To remove the surplus of larger components, the NCT was filtered through six layers of cheesecloth as previously stated (extracts $F$ or filtrates). After filtering, a volume of each type of filtrate was centrifuged at $10000 \mathrm{rev} / \mathrm{min}$ for $10 \mathrm{~min}$ to remove any remaining organic matter, and then sterilized via microfiltration through sterilized $0.22 \mathrm{~m}$ pore size (Millipore ${ }^{\circledR}$ ) membranes (extracts $\mathrm{M}$ ). The filtrates were previously filtered using prefilters with a higher pore size $\left(0.45 \mathrm{~m}\right.$ Millipore $\left.{ }^{\circledR}\right)$ during the preparation process. The PDA was sterilized and chilled to a temperature of $45^{\circ} \mathrm{C}$ after sterilizing the filtrates in an autoclave at a temperature of $120{ }^{\circ} \mathrm{C}$ for $30 \mathrm{~min}$ to deactivate the living components (extracts E) (Diánez et al. 2006). The extracts were then combined with the cooled PDA and put into Petri dishes at varied concentrations (10\%, 20\%, 30\%, and 50\%) (Diánez et al. 2006). Instead of compost teas, the controls used pure water. Individually inoculated agar plugs (with a $0.5 \mathrm{~cm}$ diameter) that were covered with the actively growing mycelia of the tested pathogens were placed on the media and cultured in the dark for $3 \mathrm{~d}$ to $7 \mathrm{~d}$ at a temperature of $25^{\circ} \mathrm{C}$. When the incubation time was over, the incubation period was over. The mycelial growth of each fungus was assessed as the average of two perpendicular colony diameters, and the inhibition effect was determined in comparison to the controls. All of the trials were carried out in a five-repetition totally randomized design.

Effect of compost tea on disease incidence and growth parameters of bean plants infected with Rhizoctonia solani in pot experiment

The inoculum prepared by five discs (with a $0.5 \mathrm{~cm}$ diameter), taken from $4 \mathrm{~d}$ old cultures of $R$. solani grown on PDA medium, were introduced into $500 \mathrm{~mL}$ bottles containing sand cornmeal medium (SCM), then incubated at a temperature of $26{ }^{\circ} \mathrm{C} \pm 2{ }^{\circ} \mathrm{C}$ for $15 \mathrm{~d}$ (Shehata 2001).

The inoculums of $R$. solani were added to sterilized Plastic pots (with a $17 \mathrm{~cm}$ diameter and a $20 \mathrm{~cm}$ height) containing $2.5 \mathrm{~kg}$ of soil at the level of $1 \mathrm{~g}$ of inoculum per $1 \mathrm{~kg}$ of soil, then watered every day for $7 \mathrm{~d}$ (El-Sherbiny 2001). The experimental design can be summarized as follows: $\mathrm{C}$ is the control, $\mathrm{P}$ is the pathogen $(R$. solani), $\mathrm{P}+\mathrm{F}$ is the pathogen + fungicide, and $\mathrm{P}+\mathrm{COM}$ is the pathogen + compost tea. The susceptible seeds ( $P$. vulgaris (Giza6)) were soaked for 1 to $2 \mathrm{~h}$ in the filtrate from compost tea at a concentration of $30 \%$. Other seeds were also immersed for the same amount of time in water as the control. The fungicide Rizolex-T was used in this experiment for comparison, using the dosage recommended by the Ministry of Agriculture $(3 \mathrm{~g} / \mathrm{L})$. The seeds were then placed on sterilized tissue paper at room temperature until dried. Five seeds were planted in each pot, and 3 pots were used for each treatment. As shown in Eq. 1, the disease incidence rate was measured $15 \mathrm{~d}$ after sowing for pre-emergence damping-off and after $30 \mathrm{~d}$ for post-emergence damping-off. The percentage of surviving plants (\% survival) was calculated $45 \mathrm{~d}$ after sowing for each treatment, as shown in Eq. 2.

For each treatment, three plants were harvested and carefully washed with running water to eliminate soil particles. The measured parameters of the bean plants are as follows: the shoot length $(\mathrm{cm})$, the root length $(\mathrm{cm})$, the number of leaves, the fresh and dry weight 
of the shoot $(\mathrm{g})$, the fresh and dry weight of the root $(\mathrm{g})$, the number of wilting plants, and the total number of plants. Folin Ciocalteau reagent was used to estimate the total phenol content according to the method outlined in (Maliak and Singh 1980). The root surface area was measured via the displacement method in a cylinder with distilled water and measured in centimeters.

\section{Statistical Analysis}

All reported values are the average of three measurements. The data were statistically evaluated using one-way analysis of variance (ANOVA) with SPSS (Version 10 ). The LSD stands for the least significant difference ( $p$-value equals 0.05 ) and was shortened as LSD.

\section{RESULTS AND DISCUSSION}

\section{Isolation, Purification, and Identification of the Causative Organism of Damping-off Disease in Beans}

Based on the morphological and microscopical characteristics, the isolated causative organism of damping-off disease in bean roots ( $P$. vulgaris), collected from different regions of the Elmenofya governorate (Shebin Elcom, Kafr Dawood, and Bader), was recognized as $R$. solani (as shown in Fig. 1). The identification was confirmed by the Mycology Center at the Assuit University (Asyut, Egypt), specifically as R. solani 6590 AUMC.

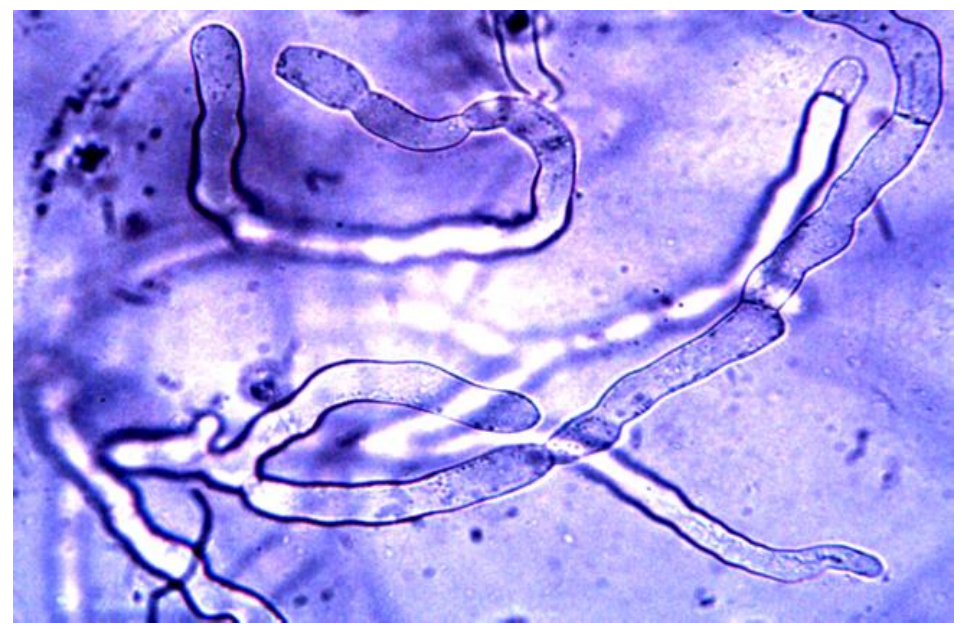

Fig. 1. Mycelium of $R$. solani, shown via light microscopy(x400)

\section{Pathogenicity test of Rhizoctonia solani}

The isolates of $R$. solani obtained from the infected bean roots were examined to determine their pathogenicity on healthy bean plants (Giza 6). The results revealed that all isolates were pathogenic and caused typical damping-off syndrome symptoms (as shown in Figs. 2 and 3), while the control plants showed no symptoms (as shown in Fig. 4). $R$. soloni isolated from Kafr Dawoad (R1) had the highest damping-off values, i.e., the plant survival rate was $12 \%$, which was lower compared with the other isolates locations (as shown in Table 1). As a result, this isolate was deemed the most aggressive and was employed in further research. 


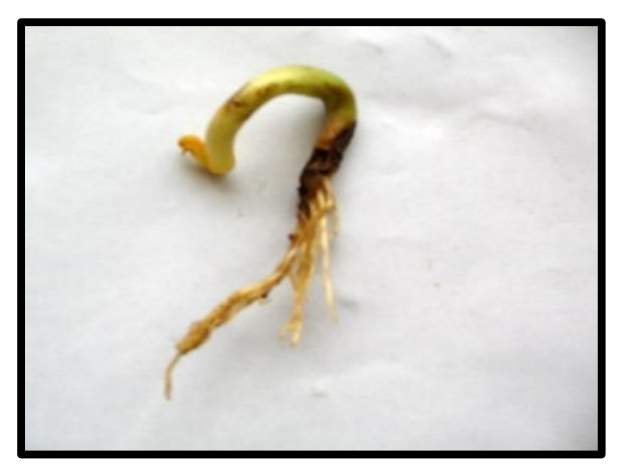

Fig. 2. Infected seed showing pre-damping-off disease Rhizoctonia infection on bean plants $15 \mathrm{~d}$ post inoculation

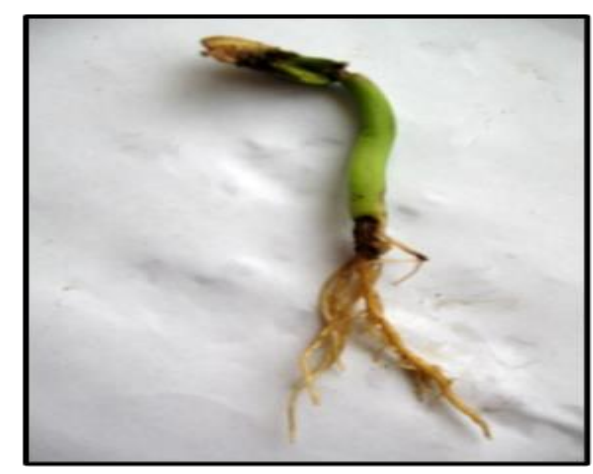

Fig. 3. Infected seedling showing post-damping off disease symptoms of Rhizoctonia infection on bean plants 30 days post inoculation

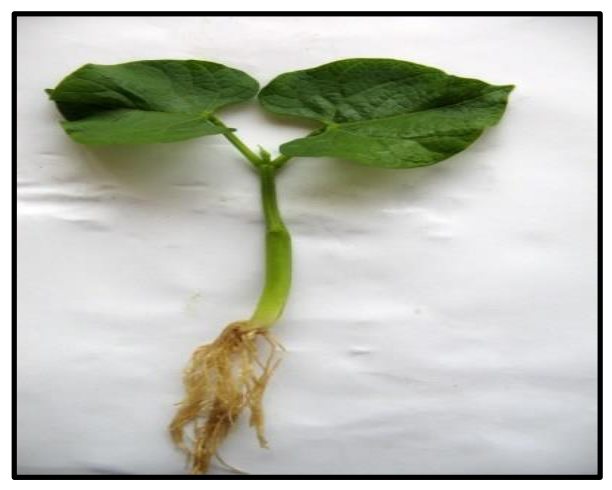

Fig. 4. Healthy bean seedling at 30 days of growth

Table 1. Pathogenicity Test for the Different Isolates of Rhizoctonia solani

\begin{tabular}{|c|c|c|c|c|c|c|c|}
\hline \multirow{2}{*}{ Isolate } & \multirow{2}{*}{ Location } & \multirow{2}{*}{$\begin{array}{c}\text { Total } \\
\text { Number } \\
\text { of } \\
\text { Seeds }\end{array}$} & \multicolumn{2}{|c|}{$\begin{array}{c}\text { Pre-emergence } \\
\text { Damping-off }\end{array}$} & \multirow{2}{*}{$\begin{array}{l}\text { Post - } \\
\text { emergence } \\
\text { Damping-off }\end{array}$} & \multirow{2}{*}{ Survival } & \multirow{2}{*}{$\begin{array}{c}\text { Plant } \\
\text { Survival } \\
(\%)\end{array}$} \\
\hline & & & $\begin{array}{l}\text { Seeds } \\
\text { Rotted }\end{array}$ & $\begin{array}{l}\text { Seedlings } \\
\text { Rotted }\end{array}$ & & & \\
\hline R1 & Kafr Dawoad & 25 & 9 & 10 & 3 & 3 & 12 \\
\hline $\mathrm{R} 2$ & $\begin{array}{c}\text { Shebin El } \\
\text { kcm }\end{array}$ & 25 & 8 & 10 & 2 & 5 & 20 \\
\hline R3 & Bader & 25 & 8 & 9 & 2 & 6 & 24 \\
\hline
\end{tabular}


Physicochemical analysis of compost tea

The physicochemical properties of the tested compost tea were analyzed in the Central Lab, Faulty of Agriculture at the Ain Shams University (Cairo, Egypt). The results showed a high amount of dissolved solids $\left(7070 \mathrm{mgL}^{-1}\right)$, organic matter $\left(1280 \mathrm{mgL}^{-1}\right)$, nitrate $\left(3840 \mathrm{mgL}^{-1}\right)$, and ammonium $\left(90.0 \mathrm{mgL}^{-1}\right)$ (as shown in Table 2). The $\mathrm{pH}$ of the compost tea was 8.50 and the electric conductivity was $11.04 \mathrm{dsm}^{-1}$. The concentration of elements phosphorus, potassium, calcium, and magnesium were $22.7,1540,214$, and 2.40 $\mathrm{mgL}^{-1}$, respectively.

Table 2. Physicochemical Analysis of Tested Compost Tea

\begin{tabular}{|c|c|}
\hline Physicochemical Properties & Value \\
\hline Acidity $(\mathrm{pH})$ & 8.50 \\
\hline Electric conductivity (EC) & $11.04 \mathrm{dSm}^{-1}$ \\
\hline Total dissolved solids (TDS) & $7070 \mathrm{mgL}^{-1}$ \\
\hline Organic Matter (OM) & $1280 \mathrm{mgL}^{-1}$ \\
\hline Ammonium $\left(\mathrm{NH}_{4}{ }^{+}\right)$ & $90.00 \mathrm{mgL}^{-1}$ \\
\hline Nitrate $\left(\mathrm{NO}_{3}-\right)$ & $3840 \mathrm{mgL}^{-1}$ \\
\hline Phosphorus (P) & $23 \mathrm{mgL}^{-1}$ \\
\hline Potassium (K) & $1540 \mathrm{mgL}^{-1}$ \\
\hline Calcium (Ca) & $214 \mathrm{mgL}^{-1}$ \\
\hline Magnesium (Mg) & $52 \mathrm{mgL}^{-1}$ \\
\hline
\end{tabular}

Effect of compost tea on the mycelia growth of Rhizoctonia solani

The mycelial growth of the pathogens studied ( $R$. solani) was suppressed by the compost tea filtrate (as shown in Table 3 and Fig. 6). The results revealed that an increase in compost tea concentration led to an increase in inhibition of mycelial growth of the tested phytopathogenic fungus. The highest inhibition of the mycelial growth of $R$. solani at a concentration of $30 \%$ was $87.0 \%$, and complete inhibition observed at a concentration of $50 \%$, which yielded a $100 \%$ reduction in mycelium growth when compared to the control treatment.

Table 3. Effect of Compost Tea on Mycelia Growth of Tested Rhizoctonia solani

\begin{tabular}{|c|c|c|}
\hline \multirow{2}{*}{$\begin{array}{c}\text { Filtrate } \\
\text { Concentration } \\
\text { of Compost Tea }\end{array}$} & Mycelial Growth (mm) & Inhibition (\%) \\
\cline { 2 - 3 } & 90 & 0.00 \\
\hline Control & 35 & 61.11 \\
\hline $10 \%$ & 26.7 & 70.33 \\
\hline $20 \%$ & 11.7 & 87.00 \\
\hline $30 \%$ & 00.00 & 00.00 \\
\hline $50 \%$ & \multicolumn{2}{|c|}{} \\
\hline \multicolumn{2}{|l}{} \\
\hline
\end{tabular}




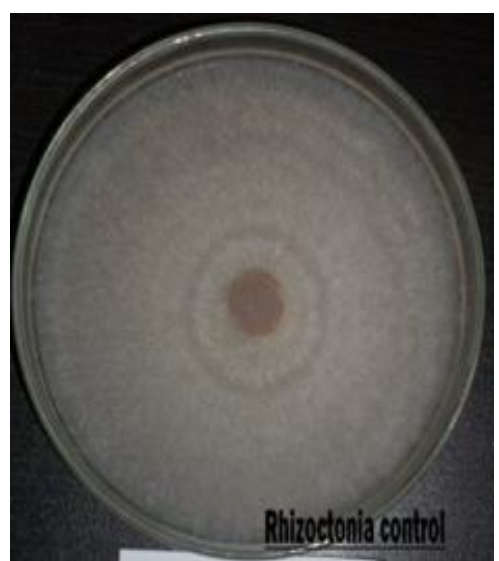

(A) Control

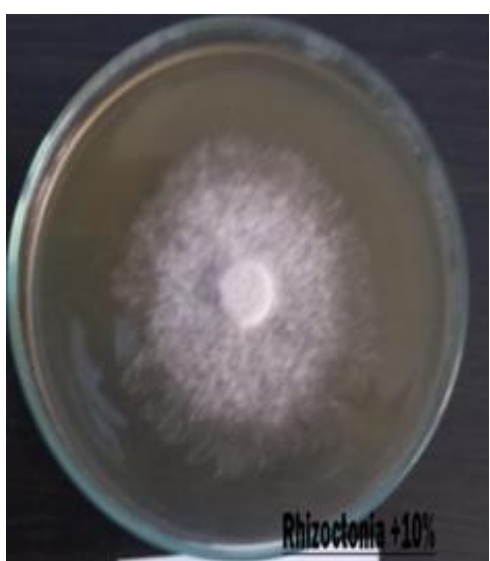

(B) R. solani $=+10 \%$

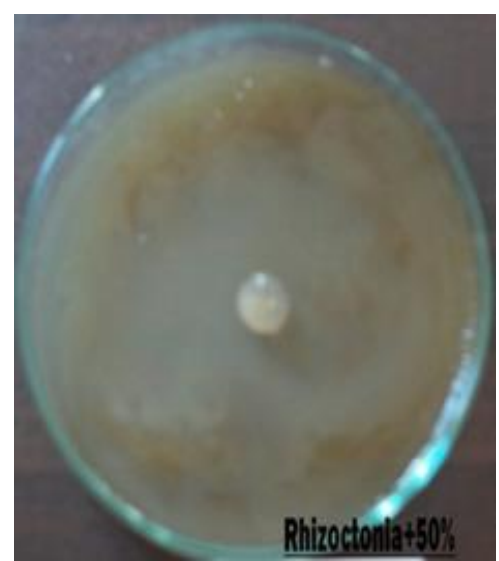

(C) R. solani $+50 \%$

Fig. 5. Effect of different compost tea concentrations (\%) on the mycelia growth of $R$. solani.

\section{Pot Experiment (Effect of Compost Tea on Disease Incidence of Damping Off Disease and Growth Parameters on R. Solani Infected Bean Plants)}

Disease incidence

The data in Table 4 showed that in bean plants infected with $R$. solani there was significant pre- and post-emergence damping-off, as well as a low plant survival rate. The application of the compost tea or the fungicide Rizolex-T to the infected bean plants significantly decreased the pre- and post-emergence damping-off and increased the plant survival rate. The decrease in damping off disease was higher in plants treated with compost tea compared to those treated with Rizolex-T.

Table 4. Effect of Compost Tea in Terms of Disease Incidence of Damping-off Disease in Bean Plants Infected with Rhizoctonia solani

\begin{tabular}{|c|c|c|c|c|c|c|}
\hline \multirow{2}{*}{ Treatment } & \multirow{2}{*}{$\begin{array}{l}\text { Total } \\
\text { Seeds }\end{array}$} & \multicolumn{2}{|c|}{ Pre-emergency Damping-off } & \multirow{2}{*}{$\begin{array}{c}\text { Post- } \\
\text { emergence } \\
\text { Damping-off }\end{array}$} & \multirow{2}{*}{ Survival } & \multirow{2}{*}{$\begin{array}{c}\text { Plant } \\
\text { Surviva } \\
(\%)\end{array}$} \\
\hline & & $\begin{array}{l}\text { Seeds } \\
\text { Rotted }\end{array}$ & $\begin{array}{l}\text { Seedlings } \\
\text { Rotted }\end{array}$ & & & \\
\hline C & 25 & 4 & 1 & 0 & 20 & 18 \\
\hline$P$ & 25 & 71 & 7 & 4 & 3 & 12 \\
\hline $\mathrm{P}+\mathrm{F}$ & 25 & 3 & 2 & 1 & 19 & 76 \\
\hline $\mathrm{P}+\mathrm{COM}$ & 25 & 4 & 2 & 0 & 19 & 76 \\
\hline
\end{tabular}

Note: Each statistic is the average of three replicates; $\mathrm{C}=$ (control), $\mathrm{P}=$ (pathogen) $(R$. solani), $\mathrm{F}=$ (fungicide), and $\mathrm{COM}=$ (compost tea)

\section{Growth Parameters}

Table 5 shows that when the bean plants were infected with $R$. solani, all growth responses, i.e., the root length, root fresh and dry weight, shoot length, shoot fresh and dry weight, and number of leaves, were considerably reduced compared to uninfected plants. The growth responses of the bean plants were greatly improved when compost tea was applied. The root length $(2.8 \mathrm{~cm})$, fresh weight $(30 \mathrm{~g})$, dry weight $(4.90 \mathrm{~g})$, shoot length $(5.89 \mathrm{~cm})$, fresh weight $(39.6 \mathrm{~g})$, dry weight $(8.17 \mathrm{~g})$, and number of leaves were all measured (9). 
Table 5. Effect of Compost Tea on Growth Parameters of Bean Plant Infected with Rhizoctonia solani

\begin{tabular}{|c|c|c|c|c|c|c|c|}
\hline \multirow{2}{*}{ Treatment } & \multicolumn{7}{|c|}{ Growth Parameters* } \\
\cline { 2 - 8 } & $\begin{array}{c}\text { Root } \\
\text { Length } \\
(\mathrm{cm})\end{array}$ & $\begin{array}{c}\text { Root Fresh } \\
\text { Weight (g) }\end{array}$ & $\begin{array}{c}\text { Root Dried } \\
\text { Weight(g) }\end{array}$ & $\begin{array}{c}\text { Shoot } \\
\text { Length }(\mathrm{cm})\end{array}$ & $\begin{array}{c}\text { Shoot Fresh } \\
\text { Weight (g) }\end{array}$ & $\begin{array}{c}\text { Shoot Dried } \\
\text { Weight (g) }\end{array}$ & $\begin{array}{c}\text { Number } \\
\text { of } \\
\text { Leaves }\end{array}$ \\
\hline $\mathrm{C}$ & $2.6^{\mathrm{a}}$ & $24^{\mathrm{b}}$ & $3.87^{\mathrm{a}}$ & $3.9^{\mathrm{b}}$ & $32.0^{\mathrm{b}}$ & $5.90^{\mathrm{c}}$ & $8^{\mathrm{ab}}$ \\
\hline $\mathrm{P}$ & $1.7^{\mathrm{c}}$ & $10^{\mathrm{d}}$ & $0.54^{\mathrm{c}}$ & $2.18^{\mathrm{bc}}$ & $19.30^{\mathrm{c}}$ & $1.89^{\mathrm{d}}$ & $5^{\mathrm{d}}$ \\
\hline $\mathrm{P}+\mathrm{F}$ & $2.1^{\mathrm{b}}$ & $19^{\mathrm{c}}$ & $2.28^{\mathrm{b}}$ & $5.0^{\mathrm{a}}$ & $33.9^{\mathrm{b}}$ & $6.99^{\mathrm{b}}$ & $6^{\mathrm{cd}}$ \\
\hline $\mathrm{P}+\mathrm{COM}$ & $2.8^{\mathrm{a}}$ & $30^{\mathrm{a}}$ & $4.90^{\mathrm{a}}$ & $5.89^{\mathrm{a}}$ & $39.6^{\mathrm{a}}$ & $8.17^{\mathrm{a}}$ & $9^{\mathrm{cb}}$ \\
\hline $\mathrm{LSD}$ & 1.65 & 3.24 & 1.26 & 2.33 & 1.78 & 1.18 & 1.92 \\
\hline $\begin{array}{l}\text { Note: Each statistic is the average of three replicates; means having same alphabetical letter in } \\
\text { column, within a comparable group of means, do not significantly differ, using Duncan's multiple range } \\
\text { test procedure at a p-value of 0.05 level of significance; C = (control), P = (pathogen) (R. solani), F= } \\
\text { (fungicide), and COM=(compost tea) }\end{array}$
\end{tabular}

\section{Total Phenol Content and Root Surface Area}

The total phenol content and root surface areas of bean plants infected and treated with compost tea or the fungicide Rizolex-T are represented in Table 6. In spite of the increased total phenol content in bean plants infected with $R$. solani, the treatment of the infected plants via compost tea or the Rizolex-T caused additional elevation in the total phenol content. The elevation in the phenol content of infected bean plants was the highest in case of the application of the compost tea $\left(17.5 \mathrm{ug} \cdot \mathrm{g}^{-1}\right.$ fresh weight). The results also showed that the plants without treatment infected with $R$. solani had a low root surface area $(1.5 \mathrm{~cm})$ compared to the control plants. However, the infected plants treated with compost tea had a high root surface area $(6.5 \mathrm{~cm})$ (Table 6).

Table 6. Effect of Compost Tea on Bean Plants Infected with Rhizoctonia solani on the Total Phenol Content (ug. $\mathrm{g}^{-1} \mathrm{dry}$ weight) and Root Surface Area

\begin{tabular}{|c|c|c|}
\hline Treatment & $\begin{array}{c}\text { Total Phenol Content } \\
\left(\text { ug. } \cdot g^{-1} \text { fresh weight) }\right.\end{array}$ & $\begin{array}{c}\text { Root Surface Area } \\
(\mathrm{cm})^{*}\end{array}$ \\
\hline $\mathrm{C}$ & $12.45^{\mathrm{c}}$ & $5^{\mathrm{b}}$ \\
\hline $\mathrm{P}$ & $15.55^{\mathrm{ab}}$ & $1.5^{\mathrm{c}}$ \\
\hline $\mathrm{P}+\mathrm{F}$ & $14.67^{\mathrm{abc}}$ & $5.5^{\mathrm{ab}}$ \\
\hline $\mathrm{P}+\mathrm{COM}$ & $17.50^{\mathrm{ab}}$ & $6.5^{\mathrm{a}}$ \\
\hline LSD & 3.12 & \\
\hline $\begin{array}{l}\text { *Note: Each statistic is the average of three replicates; means having same alphabetical letter in } \\
\text { column, within a comparable group of means, do not significantly differ, using Duncan's multiple } \\
\text { range test procedure at a } p \text {-value of } 0.05 \text { level of significance; } \mathrm{C}=\text { (control), } \mathrm{P}=\text { (pathogen) }(R . \\
\text { solani), } \mathrm{F}=\text { (fungicide), and COM = (compost tea) }\end{array}$ \\
\hline
\end{tabular}

\section{DISCUSSION}

The physicochemical properties of the tested compost tea (as shown in Table 2) showed that it had a high total amount of dissolved solids $\left(7070 \mathrm{mgL}^{-1}\right)$, organic matter (1280 $\left.\mathrm{mgL}^{-1}\right)$, nitrate $\left(3840 \mathrm{mgL}^{-1}\right)$, and ammonium $\left(90.0 \mathrm{mgL}^{-1}\right)$. The $\mathrm{pH}$ of the compost 
tea was 8.50 , and the electric conductivity was $11.04 \mathrm{dsm}^{-1}$. The concentration of elements phosphorus, potassium, calcium, and magnesium were $22.7,1540,214$, and $2.40 \mathrm{mgL}^{-1}$, respectively. During the compost tea development procedure, microorganisms from the compost colonized water were extracted and multiplied. Compost teas are used in crops to achieve two primary goals: plant growth stimulation and phytopathogen control in the air and on the ground (Scheuerell and Mahaffee 2002). To meet these goals, the physical and chemical features of the nutrients in compost teas, the humic components in the teas, or a combination of both, may increase plant nutrition, be directly toxic to pathogens, and/or induce systemic resistance to pathogens (Koné 2009). However, compost teas are also hypothesized to work as a pathogen biocontrol agent by promoting the growth of beneficial bacteria on leaf and root surfaces (Diánez et al. 2006).

The filtrate of the compost tea inhibited the mycelial growth of the tested pathogens (R. solani), as shown in Table 3 and Fig. 5. The results revealed that an increase in compost tea concentration led to an increase in inhibition of mycelial growth of the tested phytopathogenic fungus. González-Hernández et al. (2021) recorded that compost teas contributed significantly to in vitro decrement of the development and proliferation of $R$. solani growth. However many plant pathogens were shown to be inhibited by compost tea such as Phytophthora infestans (Al-Mughrabi 2007), Alternaria alternata, Botrytis cinerea and Pyrenochaeta lycopersici (Pane et al. 2012).

The highest inhibition of the mycelial growth of $R$. solani at a concentration of $30 \%$ was $87.0 \%$, and complete inhibition observed at a concentration of $50 \%$, which yielded a $100 \%$ reduction in mycelium growth when compared to the control treatment. However, Diánez et al. (2006) investigated non-aerated compost tea (NCT) for its ability to inhibit illness in vivo, and the results showed considerably a reduced incidence of $R$. solani. The data presented in Table 4 showed that there was a high frequency of pre- and postemergence damping-off and a low percentage of plant survival in bean plants infected with $R$. solani. The application of the compost tea or the fungicide Rizolex-T to the infected bean plants significantly decreased the pre- and post-emergence damping-off and increased the plant survival percentage. The decrease in damping off disease was higher in plants treated with the compost tea than the decrease in plants treated with the fungicide RizolexT. For this reason, the application of compost tea as a potential safe sustainable instead of synthetic fungicides has been growing in recent decade.

The results presented in Table 5 showed that the infection of bean plants with $R$. solani significantly decreased all the growth responses, while the application of compost tea significantly enhanced the growth responses of bean plants when compared with the control plants. The present results showed that compost tea not only suppress the pathogen or protect plant from $R$. solani but also encourages plant development, as well as reported in another studies (Ros et al. 2020; González-Hernández et al. 2021).

Composting also improves soil physical conditions by providing energy for microorganism activity and improving nutrient availability and uptake, which boosts vegetative development (Ehaliotis et al. 2005). The combination impact (which comprises of humic acids, vitamins, amino acids, and both macro and micronutrients that boost plant growth), which contains some growth regulators, e.g., cytokinins, may be responsible for the stimulation of plant growth via compost tea (Brain et al. 1973).

Numerous studies (Suárez-Estrella et al. 2012; Tian and Zheng 2013) investigated the suppressive impact of several compost teas in vitro but the current results reflect the inhibitory action of compost tea in vitro and in vivo against $R$. solani 
Compost tea is a type of compost rich in beneficial microorganisms, which help in suppressing plant diseases and improving plant health and quality (Kim et al. 2015). The production factors can affect the effectiveness of the disease control via compost tea. Generally, compost with high microbial populations and nutrients is most appropriate for the production of compost tea with high plant disease suppressive properties (St. Martin 2014). Thus, improving the compost tea with biocontrol agents and/or nutrients is a trend that many researchers in the field of plant management of disease are implementing (Siddiqui et al. 2008). Tegegn (2017) mentioned that the efficiency of compost tea in outcompeting plant pathogens may be attributed to its richness in microorganisms that act via different mechanisms, e.g., competition for nutrients, production of antibiotic and lytic enzymes, parasitism, and induction of systemic acquired resistance.

\section{CONCLUSIONS}

1. These results provided evidence that the compost extract has the potential to become a good method for biological control against soil borne fungi.

2. Compost tea is considered a safe alternative to the use of synthetic fungicides, and as a crop promoter.

3. Extract of compost tea relevant the presence of bioactive component which seem to performance a critical role in plant development and protection.

4. Application of 30 and $50 \%$ compost tea extraction caused a $87.0 \%$, and $100 \%$ inhibition to $R$. solani, respectively.

\section{ACKNOWLEDGMENTS}

For University of each author.

\section{REFERENCES CITED}

Abdel-Ghany, T. M., and Bakri, M. M. (2019). "Effectiveness of a biological agent (Trichoderma harzianum and its culture filtrate) and a fungicide (methyl benzimacold-2-ylcarbamate) on the tomato rotting activity (growth, celluloytic, and pectinolytic activities) of Alternaria solani," BioResources 14(1), 1591-1602. DOI: 10.15376/biores.14.1.1591-1602

Abdel-Ghany, T. M., Eman, M., El-Taher, and El-Sheikh, H. H. (2009). "Efficacy of fungal rust disease on willow plant in Egypt," Australian Journal of Basic and Applied Sciences 3(3), 1527-1539.

Abiot, M. A. (2018). "The effect of soil moisture level on growing of two common bean (Phaseolus vulgaris L) cultivars," Modern Approaches in Oceanography and Petrochemical Sciences 1(2), 1-4. DOI: 10.32474/MAOPS.2018.01.000108

Al-Dahmani, J. H., Abbasi, P. A., Miller, S. A., and Hoitink, H. A. J. (2003). "Suppression of bacterial spot of tomato with foliar sprays of compost extracts under greenhouse and field conditions," Plant Disease 87, 913-919.

DOI: 10.1094/PDIS.2003.87.8.913 
Al-Mughrabi, K. I. (2007). "Suppression of Phytophthora infestans in potatoes by foliar application of food nutrients and compost tea," Australian Journal of Basic and Applied Sciences 1(4), 785-792.

Al-Mughrabi, K. I., Bertheleme, C., Livingston, T., Burgoyne, A., Poirier, R., and Vikram, A. (2008). "Aerobic compost tea, compost and a combination of both reduce the severity of common scab (Streptomyces scabiei) on potato tubers," Journal of Plant Sciences 3(2), 168-175. DOI: 10.3923/jps.2008.168.175

Brain, K. R., Chalopin, M. C., Turner, T. D., Blunden, G., and Wildgoose, P. B. (1973). "Cytokinin activity of commercial aqueous seaweed extract," Plant Science Letters 1(6), 241-245. DOI: 10.1016/0304-4211(73)90026-6

Cronin, M. J., Tohalem, D. S., Harris, R. F., and Andrews, J. H. (1996). "Putative mechanism and dynamics of inhibition of the apple scab pathogen Venturia inaequalis by compost extracts," Soil Biology and Biochemistry 28(9), 1241-1249. DOI: 10.1016/0038-0717(96)00131-9

Diánez, F., Santos, M., Boix, A., Cara, M. d., Trillas, I., Avilés, M., and Tello, J. C. (2006). "Grape marc compost tea suppressiveness to plant pathogenic fungi: Role of siderophores," Compost Science \& Utilization 14(1), 48-53. DOI: 10.1080/1065657X.2006.10702262

Din, A. R. J. M., Hanapi, S. Z., Sarip, S. H. M., and Sarmidi, M. R. (2018). "Diseasesuppressive effect of compost tea against phytopathogens in sustaining herbal plant productivity," in: Applied Environmental Science and Engineering for a Sustainable Future, Z. A. Zakaria (ed.), Springer Publishing, New York, NY.

Dionne, R. J., Tweddell, H. A., and Avis, T. J. (2012). "Effect of non-aerated compost teas on damping-off pathogens of tomato," Canadian Journal of Plant Pathology 34(1), 51-57. DOI: 10.1080/07060661.2012.660195

Domsch, K. H., Gams, W., and Anderson, T. (1980). Compendium of Soil Fungi, Academic Press, London, UK.

Ehaliotis, C., Zervakis, G. I., and Karavitis, P. (2005). "Residues and by-products of olive oil mills for root-zone heating and plant nutrition," Scientia Horticulturae 106(3), 293-308. DOI: 10.1016/j.scienta.2005.04.006

El-Sherbiny, A. M. (2001). Feasibility of Using Some Plant Extracts for Biological Control of Some Plant Pathogenic Fungi, Master's Thesis, Mansoura University, Mansoura, Egypt.

González-Hernández, A. I., Suárez-Fernández, M. B., Pérez-Sánchez, R., GómezSánchez, M. Á., MoralesCorts, M. R. (2021). "Compost tea induces growth and resistance against Rhizoctonia solani and Phytophthora capsici in pepper," Agronomy 11, 781. DOI: 10.3390/ agronomy11040781

Hoitink, H. A. J., and Fahy, P. C. (1986). "Basis for the control of soilborne plant pathogens with composts," Annual Review of Phytopathology 24, 93-114. DOI: 10.1146/annurev.py.24.090186.000521

Hoitink, H. A. J., Krause, M. S., and Han, D. Y. (2001). "Spectrum and mechanisms of plant disease control with composts," in: Compost Utilization in Horticultural Cropping Systems, P. J. Stoffella and B. A. Kahn (ed.), Lewis Publishers, Boca Raton, FL.

Janisiewicz, W. J., Tworkoski, T. J., and Sharer, C. (2000). "Characterizing the mechanism of biological control of postharvest diseases on fruits with a simple method to study competition for nutrients," Phytopathology 90(11), 1196-1200. DOI: 10.1094/PHYTO.2000.90.11.1196 
Kim, M. J., Shim, C. K., Kim, Y. K., Hong, S. J., Park, J. H., Han, E. J., Kim, J. H., and Kim, S. C. (2015). "Effect of aerated compost tea on the growth promotion of lettuce, soybean, and sweet corn in organic cultivation," The Plant Pathology Journal 31(3), 259-268. DOI: 10.5423/PPJ.OA.02.2015.0024

Koné, T., Meeûs, J. d., Bouyer, S., Ravel, L., Guerrini, E., and Vial, N. L. (2010). "Population structuring of tsetse Glossina tachinoides resulting from landscape fragmentation in the Mouhoun river basin, Burkina Faso," Medical and Veterinary Entomology 24(2), 162-168. DOI: 10.1111/j.1365-2915.2010.00857.x

Mahmoud, Y. A., Gaafar, R. M., and Mubarak, H. M. (2007). "Genetic diversity among Delta isolates of Rhizoctonia solani," Turkish Journal of Botany 31(1), 19-29. DOI:

Malik, C. P., and Singh, S. P. (1980). Plant Enzymology and Histoenzymology, Kalyani Publishers, Delhi, India.

Marín, F., Santos, M., Diánez, F., Carretero, F., Gea, J. G., Yau, J. A., and Navarro, M. J. (2013). "Characters of compost teas from different sources and their suppressive effect on fungal phytopathogens," World Journal of Microbiology and Biotechnology 29, 1371-1382. DOI: 10.1007/s11274-013-1300-x

Morales-Corts, M. R., Pérez-Sánchez, R., and Gómez-Sánchez, M. Á. (2018). "Efficiency of garden waste compost teas on tomato growth and its suppressiveness against soilborne pathogens," Scientia Agricola 75(5), 400-409. DOI: 10.1590/1678992x-2016-0439

Pane, C., Celano, G., Villecco, D., and Zaccardelli, M. (2012). "Control of Botrytis cinerea, Alternaria alternata and Pyrenochaeta lycopersici on tomato with whey compost-tea applications," Crop Protection 38, 80-86. DOI:

10.1016/j.cropro.2012.03.012

Ros, M., Hurtado-Navarro, M., Giménez, A., Fernández, J. A., Egea-Gilabert, C., Lozano-Pastor, P., and Pascual, J. A. (2020). "Spraying agro-industrial compost tea on baby spinach crops: Evaluation of yield, plant quality and soil health in field experiments," Agronomy 10(3), article no. 440. DOI: 10.3390/agronomy 10030440

Saleh, S., Liu, G., Liu, M., Ji, Y., He, H., and Gruda, N. (2018). "Effect of irrigation on growth, yield and chemical composition of two green bean cultivars," Horticulturae 4(3), 1-10. DOI: 10.3390/horticulturae 4010003.

Sang, M. K., and Kim, K. D. (2011). "Biocontrol activity and primed systemic resistance by compost water extracts against anthracnoses of pepper and cucumber," Phytopathology 101(6), 732-740. DOI: 10.1016/j.apsoil.2013.01.002

Scheuerell, S. J., and Mahaffee, W. F. (2004). "Compost tea as a container medium drench for suppressing seedling damping-off caused by Pythium ultimum," Phytopathology 94(11), 1156-1163. DOI: 10.1094/PHYTO.2004.94.11.1156

Scheuerell, S., and Mahaffee, W. (2002). "Compost tea: Principles and prospects for plant disease control," Compost Science \& Utilization 10(4), 313-338. DOI: 10.1080/1065657X.2002.10702095

Shabana, Y. M. (1987). Biological Control of Water Weeds by Using Plant Pathogens, Master's Thesis, Mansoura University, Mansoura, Egypt.

Shehata, M. M. (2001). Studies on Tomato Root-Rot Disease and Their Control. Master's Thesis, Al Azharr University, Cairo, Egypt.

Siddiqui, Y., Meon, S., Ismail, M. R., and Ali, A. (2008). "Trichoderma-fortified compost extracts for the control of Choanephora wet rot in okra production," Crop Protection 27(3-5), 385-390. DOI: 10.1016/j.cropro.2007.07.002 
St. Martin, C. C. G. (2014). "Potential of compost tea for suppressing plant diseases," CAB Reviews 9, 1-38. DOI: 10.1079/PAVSNNR20149032

Suárez-Estrella, F., Bustamante, M., Moral, R., Vargas-García, M., López, M., and Moreno, J. (2012). "In vitro control of Fusarium wilt using agroindustrial subproductbased composts," Journal of Plant Pathology 94(1), 59-70. DOI: 10.4454/jpp.fa.2012.002

Tegegn, A. (2017). "Effect of aerated and non-aerated compost steepages on the severity and incidence of major fungal diseases of faba bean; Botrytis fabae, Uromyces vicia fabae and Ascochyta fabae," Plant 5(6), 85-92. DOI: 10.11648/j.plant.20170506.11

Tian, X., and Zheng, Y. (2013). "Compost teas and reused nutrient solution suppress plant pathogens in vitro," HortScience 48(4), 510-512. DOI: 10.21273/HORTSCI.48.4.510

Whipps, J. M., and Lumsden, R. D. (2001) "Commercial use of fungi as plant disease biological control agents: status and prospects," in: Fungi as Biocontrol Agents: Progress, Problems and Potential, T. M. Butt, C. Jackson, and N. Magan (ed.). CABI Publishing, Wallingford, UK.

Article submitted: June 14, 2021; Peer review completed: July 17, 2021; Revised version received and accepted: July 19, 2021; Published: July 29, 2021.

DOI: 10.15376/biores.16.3.6378-6391 